\title{
DOSSIÊ: HISTÓRIA DA CIÊNCIA
}

\section{DOSSIER: HISTORY OF SCIENCE}

DOI: http://dx.doi.org/10.15448/2178-3748.2015.2.22485

Desde fins da década de 1980, nós três temos nos dedicado a pesquisas em história das ciências. Era uma época com poucas possibilidades de atuação nas universidades brasileiras. Hoje, após quase trinta anos de muitas lutas, vemos essa área se expandir por todo Brasil. Novas gerações de pesquisadores emergem, fortalecendo nossa especialidade e disseminando os seus trabalhos nas mais diversas regiões do país. A essas novas gerações é dedicado este dossiê que tivemos um grande prazer de organizar.

Graças ao apoio da PUC-RS e da editora Tatyana Maia foi possível programar e executar a seleção de artigos que agora chegam a lume. Recebemos mais de uma dezena de artigos que foram submetidos, no sistema de avaliação cega, a pareceristas indicados por nós e pela equipe de Tatyana. Foram cerca de trinta pareceristas anônimos envolvidos na avaliação dos artigos que exigiram grande esforço em prazos reduzidos dos profissionais. Sem essa contribuição - reservada ao anonimato - não seria possível realizar a difícil e criteriosa seleção dos cinco artigos que compõem o dossiê.

Nossa satisfação em produzir este dossiê reflete também nossas trajetórias traçada ao longo de décadas em que cada um de nós três trabalhou na construção dessa área de pesquisa no país. Luiz Carlos Soares atuando na ANPUH - Associação Nacional de História - como presidente foi responsável por estabelecer a linha de pesquisa no quadro de disciplinas da História no âmbito do CNPq. Como presidente da SBHC - Sociedade Brasileira de História da Ciência - e criador do Grupo de Estudos de História da Ciência e da Tecnologia, GEHCT da ANPUH, prosseguiu na batalha de consolidação da área nos departamentos de história. Mauro Condé, como um dos criadores do SCIENTIA - Grupo de Teoria e História da Ciência - na Faculdade de Filosofia e Ciências Humanas da UFMG, produziu em Belo Horizonte um pólo importante na formação de novos pesquisadores. Carlos Maia foi um dos fundadores do NHC - Núcleo de Pesquisas em História da Ciência do CNPq - que se transformou no MAST, Museu de Astronomia, hoje, um dos centros de excelência dessa área no Brasil. Os três editaram diversos livros e organizaram outros mais. Vemos que os frutos de nosso 
trabalho, como o de muitos outros colegas, ampliou em muito as possibilidades acadêmicas de pesquisas em história das ciências.

Esse Dossiê também tem a função de apresentar aos jovens pesquisadores as oportunidades de trabalho em uma área de pesquisa inovadora dentro da disciplina história. A história das ciências vem despertando interesse crescente em inúmeros departamentos de história, o que revela uma maturidade conceitual e teórica de nossa historiografia que se renova a cada dia. Há pouco tempo ainda encontrávamos historiadores com resistência a fazer uma história do conhecimento científico. Via-se ciência como uma produção fora da história.

Mas hoje essa equação sofreu grande mudança. A atividade científica não é mais observada como se fosse uma produção estrita do pensamento de cientistas que estariam à margem da sociedade. Pensar a ciência, hoje, qualquer ciência, é vê-la como uma atividade enraizada socialmente, tão permeável aos vetores sociais quanto qualquer outra atividade humana. Essa é uma conquista teórico-metodológica de anos recentes e inaugura grandes extensões de novos territórios de pesquisa para nossos pós-graduandos.

As oportunidades para que dissertações e teses inaugurais ocorram é muito frutífera. Expandimos o horizonte de preocupações e interesses dos historiadores para terras pouco exploradas. Novas temáticas e objetos enriquecem a disciplina história e trazem mais vivacidade e desafios para os novos pesquisadores que se formam em nossas universidades. A história das ciências obriga que estejamos mais atentos aos limites teórico-conceituais disciplinares. Ela permite que se expanda esses limites. A história das ciências produz um arejamento nas velhas e consolidadas temáticas da história. Ela solicita e fornece um cabedal metodológico para quem ousa adentrar em seus temas. Não é qualquer pesquisador que se mostra capaz de identificar a historicidade do pensamento científico. Infelizmente, ainda há aqueles que nem percebem como a ciência é uma atividade historicamente situada.

Assim, convidamos os jovens pesquisadores, especialmente aqueles que ávidos por novidades e que se realizam em ousadias mais refinadas do pensamento, a se infiltrarem em nossas temáticas. Conquistem para a história essas terras devolutas que apresentam promissoras oportunidades de trabalho no Brasil. Essa é uma conquista que pode trazer uma grata satisfação profissional e um enorme prazer intelectual a todos que ingressarem na aventura de praticarem a história das ciências nos departamentos de história.

No artigo intitulado "A construção do conhecimento no instituto nacional de pesquisas da amazônia - INPA, por meio de suas expedições científicas, (1954-1975)", Ângela Nascimento dos Santos Panzu eEduardo Gomes da Silva Filho analisam a produção do Oficina do Historiador, Porto Alegre, EDIPUCRS, v. 8, n. 2, jul./dez. 2015, p. 3-6 
conhecimento científico no Instituto Nacional de Pesquisas da Amazônia - INPA, entre 1954 e 1975. Os autores procuram mostrar a constituição desse conhecimento analisando os relatórios das excursões e expedições científicas promovidas pelo Instituto na floresta Amazônica. Enfatizam o caráter coletivo da produção do conhecimento através da interação dos pesquisadores e de seus auxiliares recrutados na população local.

O artigo de Matheus Alves Duarte da Silva, "Soro ou vacina: controvérsias no controle da peste bubônica no Rio de Janeiro (1899-1901)", aborda a querela entre Oswaldo Cruz e Camilo Terni, ocorrida em 1900, acerca do tratamento das vítimas da peste. Cruz defendia a utilização do soro antipestoso como tratamento e imunização da população. Em posição contrária, o cientista italiano Camilo Terni, enviado ao Brasil para estudar a doença, por sua vez, defendia a ineficácia do soro, recomendando a vacinação da população. O embate, que teve repercussão na mídia, foi vencido por Cruz, uma vez que o soro tornou-se a arma central no combate da peste. No entanto, Duarte da Silva procura mostrar como essa vitória foi construída por alianças e interesses.

Karoline Viana Teixeira analisa, no artigo intitulado "Percepções e limites do fazer científico: o caso da Imperial Comissão Científica de Exploração (1859-1861)", aquela que é considerada a primeira viagem científica composta exclusivamente por naturalistas brasileiros, a Comissão Científica de Exploração. Essa viagem refletiu o esforço do Império brasileiro para promover descobertas que redundassem no desenvolvimento da economia brasileira, procurando seguir o exemplo das nações europeias do século XIX. Karoline Teixeira aborda, neste artigo,a experiência dessa Comissão Científica analisando as possibilidades e os limites do uso da ciência como instrumento do desenvolvimento do Império brasileiro. Império esse que lidava, por um lado, com a herança colonial mas, ao mesmo tempo, procurava se constituir como uma nação moderna e civilizada que fosse capaz de produzir conhecimento.

No artigo "Saúde e sociedade: o estudo de caso da AIDS na cidade de Itapetininga (anos 1990)", Gustavo Vargas Laprovitera Boechat parte do pressuposto de que, mais que um fenômeno biológico, a doença é um fenômeno histórico, demonstrado pelas práticas sociais e pensamentos de uma dada comunidade quando essa define seu entendimento da doença, estratégias de prevenção, concepções de transmissão e cura. $\mathrm{O}$ artigo analisa a epidemia de HIV/AIDS na cidade de Itapetininga, de 1989 a 1996. Através de uma abordagem histórica, procura compreender como, em uma cidade do interior paulista, foram incorporados discursos e práticas sobre a AIDS. Analisando a produção jornalística local, bem como os prontuários 
médicos da Santa Casa de Misericórdia de Itapetininga, Gustavo Boechat analisa o universo sócio-político e simbólico reconstruindo as vivências e representações dessa comunidade em torno da doença.

Por fim, no artigo "Análise das fichas do serviço de ortofrenia e higiene mental do Rio de Janeiro (Arthur Ramos, 1934-1939): contribuições à história da psicologia", Jefferson Mercadante analisa as fichas individuais de crianças atendidas pelo Serviço de Ortofrenia e Higiene Mental no Rio de Janeiro, entre os anos de 1934 e 1939, a partir das quais procura identificar características eugenistas presentes na atuação de Arthur Ramos à frente da Seção de Ortofrenia e Higiene Mental. Segundo Mercadante, com intuito de servir à abordagem higienista, a psicanálise freudiana foi modificada. Ainda que não possamos exatamente filiar Arthur Ramos ao ideário eugênico da teoria racial determinista - já que percebemos sua preocupação com a valorização do homem por meio da cultura e a da saúde do espírito -, em certo sentido percebemos que, na medida que em sua fala predomina a ideia de prevenção e correção por meio da educação e da higiene mental, ele termina, de certa forma, por neutralizar as causas econômicas e políticas como fortes fatores da desigualdade social. Sob esta ótica, mesmo que pareça mais preocupada com a dimensão social dos problemas psíquicos, sua obra encontra-se impregnada da mesma ideologia que postulava a construção de uma nação nova a partir da atuação do controle médico que excluísse os aspectos degenerativos e desagregadores da sociedade.

Desejamos a todos uma excelente leitura!

Carlos Alvarez Maia - UERJ

Mauro Lúcio Leitão Condé - UFMG

Luiz Carlos Soares - UFRJ 